\title{
Handling of Facts and Strategy in Cicero's Speech in Defence of King Deiotarus
}

\author{
Tamás NóTÁRI \\ Károli Gáspár University, Budapest / Faculty of Law and Political Science \\ tamasnotari@yahoo.de
}

\begin{abstract}
The three orationes Caesarianae, i.e., Pro Marcello and Pro Ligario given in 46 and Pro rege Deiotaro delivered in 45 are connected by the fact that the addressee of all of them is Caesar. The speech made in defence of King Deiotarus is the fruit (if possible) of both a legally and rhetorically critical situation: the judge of the case is identical with the injured party of the act brought as a charge: Caesar. Thus, the proceedings, conducted in the absence of the accused, in which eventually no judgment was passed, should be considered a manifestation of Caesar's arrogance, who made mockery of the lawsuit, rather than a real action-at-law. This speech has outstanding significance both in terms of the lawyer's/orator's handling of the facts of the case under circumstances far from usual, and in the development of the relation between Cicero and Caesar. We can also observe some thoughts on the theory of the state framed by Cicero, the fight against Caesar's dictatorship gaining ground, for the sake of saving the order of the state of the Republic.
\end{abstract}

Key words: Pro rege Deiotaro, Caesarianae orations, crimen maiestatis.

RECIBIDO: 4 de mayo de 2012 • ACEPTADO: 7 de enero de 2012.

In November 45, Cicero delivered his statement of the defence before Julius Caesar in favour of King Deiotarus (Pro rege Deiotaro), who, just as Q. Ligarius, sided with Pompey in the civil war. By then, in November 45, Caesar had defeated Pompey's sons in the battle at Munda; then, he held a triumphal march over them. The triumph caused huge dissatisfaction ${ }^{1}$ as triumphal marches were meant to legitimise victories over external enemies and not compatriots. ${ }^{2}$ His grandson, Castor and the one-time royal physician hired by him, Phidippus the slave acted as prosecutors of King Deiotarus; they charged the king with capital offence, ${ }^{3}$ assassination attempt against Caesar dated by them to $47^{4}$ and

\footnotetext{
${ }^{1}$ Cf. Plut. Caes. 56.7.

2 Werner 1984, p. 255.

${ }^{3}$ Cic. Deiot. 1.

${ }^{4}$ Cic. Deiot. 15.17-22.
} 
conspiracy, ${ }^{5}$ that is ${ }^{6}$ the charge can be described in brief by the facts of the case of perduellio, and crimen imminutae maiestatis. ${ }^{7}$ Cicero, who had maintained good relations with the King since he was proconsul in Cilicia, undertook the defence. ${ }^{8}$

First, we review the charge against King Deiotarus to find out if the proceedings conducted against the King can be considered a criminal action de iure at all. (I.) After that, we intend to analyse Pro rege Deiotaro as a rhetoric work with respect to the political program that appears in it and Caesar's image drawn by Cicero, (II.) which also allows examination of how Caesar's "reforms", that is, the efforts made towards eliminating the form of state of the republic, are treated and commented upon in Cicero's lifework and philosophy of the state. (III.)

\section{Historical background and procedural law awkwardnesses of Pro rege Deiotaro}

Deiotarus's situation vis-à-vis Caesar became rather unpleasant after the battle at Pharsalus, which the prosecutors did not omit to exploit for their own benefit, because in 48 he visited Pompey in his camp. Caesar, who had the integrity of Deiotarus's royal title and empire enforced in the senate as consul, interpreted this gesture as an act of ungratefulness. ${ }^{9}$ Although in 47 Deiotarus asked for the opportunity to meet Caesar to exculpate himself for his conduct that Caesar found injurious, Caesar refused the favour of a meeting, bringing it to the King's knowledge that in 48 already he was the repository of legitimacy, therefore, purely on the grounds of Roman public law Deiotarus would have been obliged to be loyal to him. ${ }^{10}$ After Pharsalus, Deiotarus sided with Caesar and supported his campaign in Alexandria, ${ }^{11}$ yet, Caesar decided that although

${ }^{5}$ Cic. Deiot. 22-25.33.

${ }^{6}$ On the political role of King Deiotarus see Niese 1901, coll. 2401-2403; Richter \& Eberhard $1904^{4}$, pp. 79 y ss.; Hoben 1969, pp. 83 y ss.

${ }^{7}$ Riemer 2001, p. 30.

${ }^{8}$ Cf. Cic. Att. 6.1.14; Deiot. 39.

${ }^{9}$ On the topic of gratia see Drexler 1988, pp. 11 y ss.

${ }^{10}$ Bringmann 1986, p. 81.

${ }^{11}$ Bell. Alex. 34.39-40; 67-70. 
Deiotarus could retain his royal dignity, he should give up a significant part of his empire. ${ }^{12}$ This dismemberment, which took place after the battle at Zela in Nikaia, ${ }^{13}$ meant the following: a part of Deiotarus's empire in Armenia was granted to Arzobarzanes, ruler of Cappadocia, and a Galatian territory was allocated to Mithridates, ruler of Pergamum. ${ }^{14}$ For a while Deiotarus hoped for the victory of Pompey's adherents in Africa, however, after their defeat he definitely distanced himself from them. ${ }^{15}$ After Mithridates's death not much later, Deiotarus attempted to get Caesar to return him the rule over the Galatian tetrarchia, which, however, Castor Saocondarus, tetrarcha and Deiotarus's son-in-law wanted to prevent by all means. ${ }^{16}$

After the battle at Munda that took place in March 45, Caesar received Deiotarus's delegation in Taracco, and in a letter addressed to the King he held out the prospect of adjudging the case favourably. ${ }^{17}$ Anticipating the adoption of this decision, Castor Saocondarus's son, Castor, Deiotarus's grandson brought a double charge against his grandfather, founding it on the testimony of the escaped slave, Phidippus, the King's former physician, claiming that he had prepared assassination attempt against Caesar - on the occasion of the visit he paid to Galatia in 47- and together with C. Caesilius Bassus he secretly plotted against Caesar. ${ }^{18}$ The prosecutors most probably founded their claim on Caesar's aversion to and bias against Deiotarus. ${ }^{19}$

By this turn the case constructed an until then unprecedented political and legal situation, namely, prior to that it had never occurred that a rex iussus was summoned before a Roman court for being charged with capital offence, to say nothing of the fact that no foedus iniquum whatsoever entered into with Deiotarus submitted the King to the jurisdiction of Rome. The charge against Deiotarus was based on the testimony of

${ }^{12}$ Cic. Deiot. 8.22.35. skk; Div. 1.27; 2.29; Phil. 2.94; Bell. Alex. 78.3. On the hand see Dio Cass. 41.63.3. Cf. Ritter 1970.

${ }^{13}$ Bell. Afr. 78; Cic. Div. 2.79; Phil. 2.94.

${ }^{14}$ Cf. Hoben 1969 , passim.

15 Cic. Deiot. 25.

${ }^{16}$ Ritter 1970 , pp. 124 y ss.

${ }^{17}$ Cic. Deiot. 38. Cf. Bringmann 1986, p. 82.

${ }^{18}$ Cic. Deiot. 38.

${ }^{19}$ Cic. Deiot. 8-9; Phil. 2.94-95. 
his slave, Phidippus, which, in addition to being morally displeasing, created an impossible legal situation since in Rome a slave was not allowed to testify against his master in a criminal action. Furthermore, it added to these awkwardnesses that in those days Deiotarus did not stay in Rome, and in accordance with the order of Roman criminal procedure no proceedings could be conducted against the accused in his absence. ${ }^{20}$ The case was made more delicate by the fact that the charge due to the assassination planned and attempted against Caesar was brought before the dictator himself, who in accordance with the principle "nemo iudex in propria causa" 21 would have by no means had the right to act as judge in the proceedings - not even in the case if he had been just as Sulla entitled to the title of dictator rei publicae constituendae (legibus scribundis), which in theory vested him with unrestricted punitive power. ${ }^{22}$ Yet, easily rising above all these reservations Caesar himself desired to proceed in King Deiotarus's case as a judge.

Cicero, as a matter of fact, did not omit to bring up these awkwardnesses, but being compelled to present these legal abuses as Caesar's merits, ${ }^{23}$ he made capital of this need, declaring that the dictator would guarantee that he should not be afraid of any inequity in the case. ${ }^{24}$ Cicero's words also reveal that Caesar did not take the principle of passing judgment in consilium $^{25}$ into account either, and the orator, while emphasising the dictator's clementia, was compelled to make the absurd charges inauthentic by weighty counter-arguments. ${ }^{26}$ Although the biography written by Suetonius on Caesar asserts that in his administration of justice he proceeded very strictly and justly, ${ }^{27}$ we can by no means take this statement to refer to Deiotarus's case, at most to the judgments passed by Caesar during the term of his proconsulate, on the one hand, and to those passed in the disputes arising from the ager publicus allo-

\footnotetext{
${ }^{20}$ See also Nótári 2003.

${ }^{21}$ C. 3.5 .

22 Mommsen 1899, pp. 35 y ss. y Kunkel 1962, pp. 21 y ss.

${ }^{23}$ See also Dahlmann 1970.

${ }^{24}$ Cic. Deiot. 4.

${ }^{25}$ On the role of consilium see Kunkel 1974, pp. 151-254.

${ }^{26}$ Cic. Deiot. 15 y ss.

${ }^{27}$ Suet. Caes. 43.1. ius laborosissime ac severissime dixit.
} 
cated to his veterans after the civil war, ${ }^{28}$ on the other. ${ }^{29}$ Consequently, the proceedings against King Deiotarus can be in no circumstances considered a criminal action; on the contrary, it provides a glaring example of Caesar's arrogance disregarding law and order of the Republic and defiantly showing off his personal power.

The outcome of the lawsuit is not known, Caesar presumably adjourned decision. ${ }^{30}$ There are good chances of excluding the opportunity of acquittal since later Cicero noted that Caesar adjudged no issue whatsoever regarding Deiotarus justly. ${ }^{31}$ Nor can it be ascertained that Deiotarus was sentenced as Cicero would have probably used the fact of death sentence as an argument against Antonius, who wanted to have a law from Caesar's purported legacy, which could be reinstated to Deiotarus's earlier reign, adopted as authentic. ${ }^{32}$ Irrespective of the result of the lawsuit, immediately after Caesar's death, Deiotarus took possession of the territories that the dictator had disannexed from him, ${ }^{33}$ and this annexation was acknowledged as lawful by a regulation made public by Antonius - presumably in return for significant valuable consideration. ${ }^{34}$

\section{Shaping Caesar's image as rhetorical tactics in Deiotariana}

Cicero begins the prooemium of his speech with an enumeration disguised as captatio benevolentiae, listing the circumstances in the proceedings that make him uneasy. The accused whose life is at stake is a King, what is more, a highly recognised friend of Rome. The prosecutors are two good-for-nothings - Deiotarus's cruel grandson and Deiotarus's bribed slave, who voluntarily testifies against his master although in Rome even during the tortures compulsory in the interrogation of slaves it was prohibited to put questions to them to which they could have made a confession incriminating their master. ${ }^{35}$ The accused is not present,

\footnotetext{
${ }^{28}$ Val. Max. 6.2.11.

${ }^{29}$ Bringmann 1986, p. 85.

${ }^{30}$ Cic. Att. 14.12.1.

${ }^{31}$ Cic. Phil. 2.95.

32 Cic. Phil. 2.93-96; Olshausen 1975, p. 123.

${ }^{33}$ Cic. Phil. 2.95.

${ }^{34}$ Cic. Att. 14.12.1; Phil. 2.93; Rochlitz 1993, pp. 130-131.

35 Schumacher 1982, pp. 38-39; Bringmann 1986, p. 83.
} 
Caesar acts as judge in his own case; the trial takes place not before the public of the Forum but in Caesar's palace. ${ }^{36}$ They key words of prooemium/exordium are metus, timor and perturbatio; however, he expresses his concerns not only due to the specific case but the general danger threatening security in law. ${ }^{37} \mathrm{He}$ draws conclusions regarding the entirety of the community from the Deiotarus case just as he did concerning the Marcellus and Ligarius case. Yet, he tries to make the impression as if sapientia, praestans singularisque natura shown by Caesar, ${ }^{38}$ his favourable countenance, ${ }^{39}$ aequitas and audiendi diligentia reassured him ${ }^{40}$ - probably in order to influence his defendant's case towards a favourable direction (insinuatio). ${ }^{41}$ However, success of Caesar's natura and sapientia might be overshadowed by public opinion. ${ }^{42} \mathrm{He}$ expects Caesar to arrive at a just outcome with regard to the proceedings, this, however, does not change his conviction that the lawsuit is a priori iniquum and a kind of attack against the fundaments of law and order. ${ }^{43}$

The concept of clementia comes up first at the beginning of the argumentatio, and appears together with the concepts of fides and constantia. ${ }^{44}$ By bringing up that Deiotarus stood by Pompey, the orator tries to take the sting out of Caesar's anger as well as reminds the dictator of his promise made to the King, specifically, that he would adopt a forgiving attitude to him. ${ }^{45}$ Again, the metus theme of the prooemium emerges, and in such form that Caesar, through the political amnesty already granted and having acknowledged his title of King and guest-friend, has brought an end to Deiotarus's desperate fear, re-ranking him from the group of enemies to the category of friends who have forgotten about their obligation. ${ }^{46} \mathrm{In}$ order to explain why Deiotarus took the position to side with Pompey by

\footnotetext{
${ }^{36}$ Rochlitz 1993, p. 135.

${ }^{37}$ Cic. Deiot. 3.

${ }^{38}$ Cic. Deiot. 4.

${ }^{39}$ Cic. Deiot. 5.

${ }^{40}$ Cic. Deiot. 7.

${ }^{41}$ Cic. Inv. 1.20.

${ }^{42}$ Olshausen 1975, pp. 121-122.

${ }^{43}$ Cic. Deiot. 4.

${ }^{44}$ Cic. Deiot. 8.

${ }^{45}$ Cic. Deiot. 8.

${ }^{46}$ Rochlitz 1993, p. 136.
} 
"erroneously" sizing up the situation of internal politics in Rome ${ }^{47}$ he extends the arguments to cover all of the adherents of Pompey, and tries to interpret it as loyalty to legitimate institutions, and, first touching on the King's case solely in terms of public law/politics and not criminal law, he draws general conclusions regarding the community. ${ }^{48}$ It was clementia showed by Caesar earlier that brought an end to the community's metus and timor, and in the future this virtue is no longer formulated as the consequence of personal mood or decision but as a requirement with binding force that the dictator should meet. ${ }^{49}$ The motif of fear is carried through the whole speech as it were as a Leitmotiv: if Caesar did not feel that his given word was binding upon him, then he would become a tyrant, who excites fear and dread around him. ${ }^{50}$ In Pro Ligario ${ }^{51}$ and Pro Marcello $^{52}$ - contrary to Pro rege Deiotaro - it is just lack of fear that the orator stresses; i.e., that he need not be terrified of speaking honestly before Caesar.

Accordingly, the content of the meaning of clementia is modified: the emphasis is shifted from Caesar's personal generosity expressed in Pro Marcello and from the inclination to forgive for error underlined in Pro Ligario to the requirement of the steadiness of political clementia practised earlier. ${ }^{53}$ Fides and constantia to be adopted in exercising clementia come to the front, and Cicero - after brief refutation of the assassination attempt, transferring the matter from criminal law to the plane of politics - addresses Caesar not as a judge but as a dictator. So, if Caesar wants to avoid to be looked at as a tyrant, he must consistently keep to his earlier principles. Refuting the arguments of the prosecution, he quotes a letter of Blesamius, a subject of Deiotarus, in which - presenting these statements as gossip in bad faith - he voices his view that Caesar is already considered a tyrant because he had his statue erected beside the statues of kings. ${ }^{54}$ The orator himself neither confirms, nor

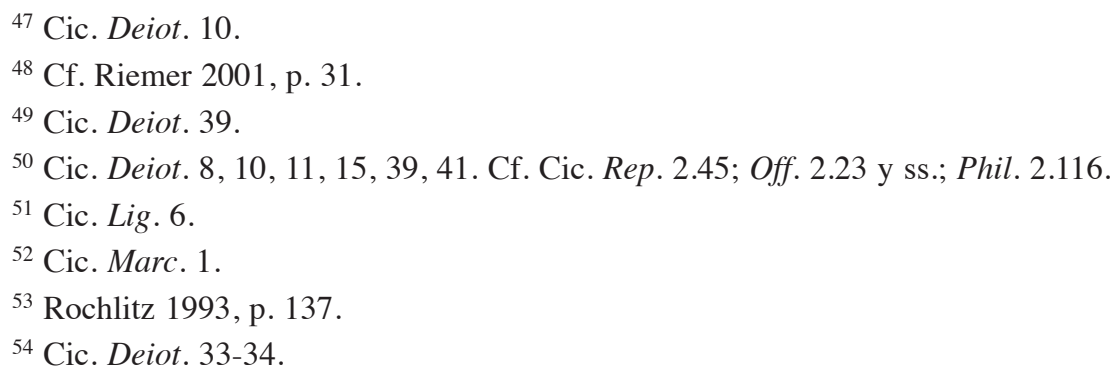


refutes the charge of tyranny, ${ }^{55}$ instead, he points out that contrary to Deiotarus's subjects he and his fellow-citizens were born as free men in a free Roman state - which implies a bitter contrast with the present, Caesar's dictatorship, ${ }^{56}$ especially because Cicero does not conceal the rage and anger manifested by Caesar either. ${ }^{57}$

Reference to Caesar's clementia sometimes does not lack ironic overtones since Cicero relates that in 47, owing to Caesar, Deiotarus, having been deprived of the major part of his territories by the resolution adopted in Nicaea, could contemplate with a philosopher's quietude in the evening of his life for he had been relieved of the burdens of ruling. ${ }^{58}$ Antiochus paid the same price for furor as Deiotarus for an excusable error $^{59}$ - all that highly questions the value of Caesar's clementia. Albeit, in the form of a rhetorical question he denies that Deiotarus can suffer any further loss and damage through grave iniuria ${ }^{60}$ - but reference to this opportunity in the form of denial indicates the opportunity of grave iniuria as real danger: the King being sentenced by Caesar. It is just this iniuria that is the most important characteristics of tyranny, and if Caesar withdrew the pardon granted earlier, he would inevitably draw the charge of tyranny against him. ${ }^{61}$

So, Cicero formulates a kind of "warning" to Caesar. If Caesar sentenced his one-time guest-friend, Deiotarus, this would remind the people of the bloodshed of Sulla; the erection of his own statue - with the inscription "Deo Invicto" in the Quirinus temple ${ }^{62}-$ is yet accepted by the people of Rome but if Caesar should go beyond that, this would amount to tyranny. ${ }^{63}$ Thus, reference to tyranny is actually made, even if only from the mouth of Deiotarus's delegates and grandson. ${ }^{64}$ This raises a question difficult to answer: whether Cicero wants to make a success

\footnotetext{
55 Botermann 1992, pp. 339 y ss.; Werner 1984, p. 250.

${ }^{56}$ Bringmann 1986, p. 344.

${ }^{57}$ Cic. Deiot. 8.9.40.

${ }^{58}$ Cic. Deiot. 38.

${ }^{59}$ Cic. Deiot. 36.

${ }^{60}$ Cic. Deiot. 37.

${ }^{61}$ Rochlitz 1993, p. 138.

${ }^{62}$ Dio Cass. 43.45.2-3.

${ }^{63}$ Klass 1939, p. 212; Hoffmann 2003.

${ }^{64}$ Riemer 2001, p. 34.
} 
of his case before Caesar merely in accordance with the situation of the present moment (as Ulrike Riemer assumes ${ }^{65}$ ) or (following the proposition of Helga Botermann and Sabine Rochlitz) the warning formulated by the orator is also a threat, which is going to be fulfilled by the Ides of March $44{ }^{66}$

At this point Cicero presents a stylised figure of Deiotarus as a kind of philosopher king, which does not correspond with the historical Deiotarus image known to us - since he did not even shrink back in fear of murder committed against his own family members ${ }^{67}$ and so much disagreed with Caesar's territorial regulations that immediately after Caesar's death he marched into his earlier provinces. ${ }^{68}$ In Cicero's presentation, however, Deiotarus becomes a King who rises above changes of fortuna and lives fully aware of his internal values, which are not only good but are sufficient for a happy life — virtus, magnitudo animi, gravitas and constantia. ${ }^{69}$ The pair of opposites of the "bonus rex Deiotarus" and the "Caesar tyrannus" becomes a ruler's mirror, similar to Pro Marcello, albeit, it makes Pro rege Deiotaro a negative ruler's mirror. Here the orator, instead of modelling the ideal ruler after Caesar, confronts the dictator with the requirements that he is to meet as reality appearing in the person of Deiotarus. Although the topos of the ruler appreciating internal values more than anything else is in line with the theme of Pro Marcello, ${ }^{70}$ in the orator's presentation, however, Deiotarus has already realised and achieved all that Cicero set as a goal to Caesar in Pro Marcello. ${ }^{71}$ The idealised and, as a matter of fact, unhistorical Deiotarus is in possession of generosity and consistency ${ }^{72}$ that Cicero deems doubtful in the case of Caesar. ${ }^{73}$

Cicero prepares the stylised Deiotarus image of the peroratio well in advance. As refutation of the assassination attempt against Caesar,

\footnotetext{
${ }^{65}$ Riemer 2001, p. 34.

${ }^{66}$ Botermann 1992, p. 344; Rochlitz 2003, pp. 134 y ss.

${ }^{67}$ Richter-Eberhard 1904, pp. 81 y s.

${ }^{68}$ Cic. Phil. 2.95.

${ }^{69}$ Cic. Deiot. 38.

${ }^{70}$ Cf. Cic. Marc. 26-30.

${ }^{71}$ Cic. Marc. 25.

${ }^{72}$ Cic. Deiot. 38.

${ }^{73}$ Rochlitz 1993, pp. 138-139.
} 
first of all he brings up Deiotarus's personality, who is characterised and guided, in addition to prudentia and virtus, by fides, religio, probitas, constantia, integritas and gravitas $^{74}$-as it were as the opposite of Caesar, whose fides and constantia can be righteously doubted by the public. To refute that after the battle at Pharsalus the King was only waiting for Caesar being defeated in the war in Africa, Cicero endows Deiotarus with several virtues that belong to the scope of temperancemansuetudo,${ }^{75}$ frugalitas, modestia, temperantia,${ }^{76}$ pudor, pudicitia ${ }^{77}$ It is especially interesting that reference is made to the virtue that is missing from the catalogue of ruler's virtues - fortitudo, iustitia, severitas, gravitas, magnitudo animi, largitio, beneficentia, liberalitas ${ }^{78}$ - the ancient Roman frugalitas, which is an asset possessed by optimus pater familias and diligentissimus agricola et pecuarius. ${ }^{79}$ Thus, this virtue characterises private persons rather than kings; ${ }^{80}$ yet, it is one of the most valuable traits beside temperantia, moderatio and modestia as a synonym of the Greek sophrosyne $\bar{e} .{ }^{81}$ It is by stressing just this virtue that he criticises Caesar who behaves more and more as a rex in Rome and has gone beyond human measure in his power ambitions. ${ }^{82}$

In the peroratio he as it were compels Caesar to make his choice: if he allows his iracundia to govern, he will be just as cruel, i.e., a tyrant, as the prosecutors; but if he lets his clementia and misericordia prevail, then he must give pardon to Deiotarus. ${ }^{83}$ Thereby he drives the dictator's attention to the point that very little - the exercise of fides and clementia- separates him from the form of ruling his power is now referred to in Rome: tyranny. Here, most of the virtues attributed to Caesar in Pro Marcello and Pro Ligario appear as features of Deiotarus only and Caesar's sapientia and aequitas are presented in much paler and more

\footnotetext{
${ }^{74}$ Cic. Deiot. 16.20.

${ }^{75}$ Cic. Deiot. 25.

${ }^{76}$ Cic. Deiot. 26.

77 Cic. Deiot. 28.

${ }^{78}$ Rochlitz 1993, p. 139.

${ }^{79}$ Cic. Deiot. 26.

${ }^{80}$ Seel 1967, p. 229.

${ }^{81}$ Cic. Tusc. 3.16 y s.; 4.36.

${ }^{82}$ Rochlitz 1993, p. 140.

${ }^{83}$ Cic. Deiot. 40.43.
} 
relative colour. Clementia Caesaris - in the meantime celebrated by official cult, which must have been rather displeasing to Cicero- emerges at more emphatic loci than in Pro Marcello, however, with strong critical and ironic overtones.

Although later on Cicero himself commented upon Pro rege Deiotaro with not much appreciation and called it oratiuncula with some disdain, the fact, however, that he edited and sent it to his friends, for example, Dolabella, as a modest gift woven by rough thread, ${ }^{84}$ implies that he attributed significance to it that pointed beyond the circumstances of the specific lawsuit, and wanted to provide publicity for it, primarily for the criticism formulated in the speech against Caesar's autocracy ${ }^{85} \mathrm{Cae}$ sar, returning in the first days of October 45 from the war in Hispania ${ }^{86}$ to Rome by triumph, started to behave more and more like a rex.$^{87}$ The cult his personality was celebrated by assumed increasingly exaggerating forms - although, as tradition has it, Cicero was the first to make proposals on acknowledgements to be granted to Caesar, while doing so he did not miss to keep sensible measure in view. ${ }^{88}$ It happened in those days that - motivated by fear, ${ }^{89}$ out of overzealousness, provocation or on Caesar's initiative ${ }^{90}$ - Caesar's statue with the inscription "Deo invicto" was erected in the Quirinus temple, ${ }^{91}$ and the senate adopted a resolution on erecting the temple of Clementia Caesaris. Much to the delight of Cicero, who saw it as a mockery of the ideal state of the Republic, the Caesar statue carried around on the occasion of Ludi Caesaris was not greeted by much jubilation by the people. ${ }^{92}$ It came out that Caesar wanted to restore the name of the state of form of the Republic only and not its core and actual aspect, ${ }^{93}$ he did not live up the hopes attached to him in Pro Marcello, and Cicero was compelled

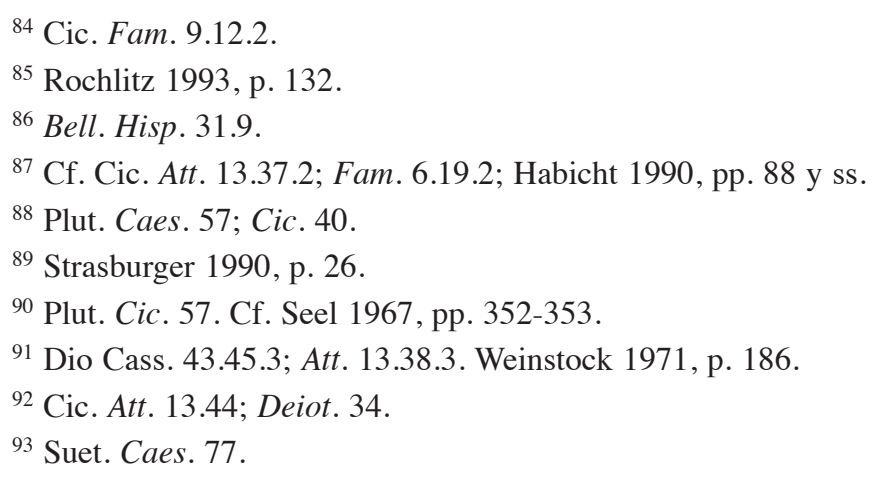


to be disappointed with him; ${ }^{94}$ yet, he could not fully back out of the impact produced by Caesar's personality. ${ }^{95}$

Caesar required the political notabilities of the age of the Republic to give evidence of passivity, silent and disciplined "adapting", "adjustment"; 96 politics were controlled by Caesar and his camarilla; ${ }^{97}$ the integrity of common sapientia appeared to be vain hope. ${ }^{98}$ Cicero was forced to remain silent on public affairs, ${ }^{99}$ he devoted himself to his philosophical works - which resulted in 45 in Hortensius, Academici libri, De finius bonorum et malorum and Tusculanae disputationesin which he resolutely criticised the general conditions of his age and Caesar's autocratic ambitions. ${ }^{100}$ In the light of that, the assessment of Pro rege Deiotaro divided the literature on the subject. Hugo Willrich, for example, evaluated it as the sign of good relations between Cicero and Caesar and as the document of Cicero's opportunism. ${ }^{101}$ Otto Seel - in addition to clearly identifiable criticism of Caesar and the general conditions - discovered in it the picture of demoralisation by power, specifically, demoralisation of both the person who exercises power and the person who bows to power, which created a humiliating, undeserved situation for both Caesar and Cicero. ${ }^{102}$ Matthias Gelzer, however, claims that the oration clearly shows how far Cicero could go even in Caesar's presence in discussing political issues and that he openly gave evidence of his values supporting the republic. ${ }^{103}$ In Pro rege Deiotaro Eckart Olshausen unambiguously discovers the reflection of Cicero using his defendant's case as a tool to enable him to reveal his thoughts before Caesar on political issues and expound his opinion on the conditions of the age. ${ }^{104}$ Helga Botermann considers this oration ultimate settlement

\footnotetext{
${ }^{94}$ Cic. Att. 14.1.2; 14.2.3.

${ }^{95}$ Cic. Att. 13.42; 14.17.6; 15.4.3.

${ }^{96}$ Strasburger 1968, p. 61.

${ }^{97}$ Cic. Fam . 6.19.2.

${ }^{98}$ Rochlitz 1993, p. 133.

${ }^{99}$ Cic. Fam. 4.6.3.

100 Strasburger 1990, p. 37.

${ }^{101}$ Willrich 1944, pp. 221 y ss.

102 Seel 1967 , pp. 350 y ss.

${ }^{103}$ Gelzer 1969, pp. 318 y s.

104 Olshausen 1975, pp. 122-123.
} 
of accounts with Caesar and his state, in which Cicero makes Caesar's state as tyranny the subject of criticism. ${ }^{105}$

Cesar's tyranny in Cicero's work and philosophy of the state

In the mirror of all that it can be declared that Cicero was deeply disappointed in his hopes attached to Caesar; 106 the gap between them became irreconcilable, and in the speech it is possible to reveal masked condemnation of Caesar and idealisation of his opponents. ${ }^{107}$ That in those days Cicero might have already thought of assassinating Caesar is revealed by a letter written to Atticus, ${ }^{108}$ in which the orator referred to Caesar's purchase of a house in Quirinal: the house stood near to the Salus and Quirinus temple, and Cicero remarked that he would like to see Caesar close to Quirinus and Quirinus's fate rather than to balanced welfare (salus), by which he clearly lets his younger brother infer identification of Romulus, assassinated according to certain traditions, with Quirinus. ${ }^{109}$

As Suetonius left it to us, in a letter Cicero purportedly writes about Caesar: when he was aedil he was already thinking about royal power, striving for royal authority. ${ }^{110}$ It is worth paying some attention to the loci where Cicero refers to Caesar as rex. The letter addressed to Atticus - which mentions Caesar with ironic overtones ${ }^{111}$ - was written on 14 August 45, ${ }^{112}$ and the one to Matius at the end of August 44. ${ }^{113}$ On the other hand, it cannot be concealed that it was not only Caesar whom Cicero called rex, earlier he called Pompey the same, however, stressing his positive traits. ${ }^{114}$ Cicero was addressed by the title rex, and, for that

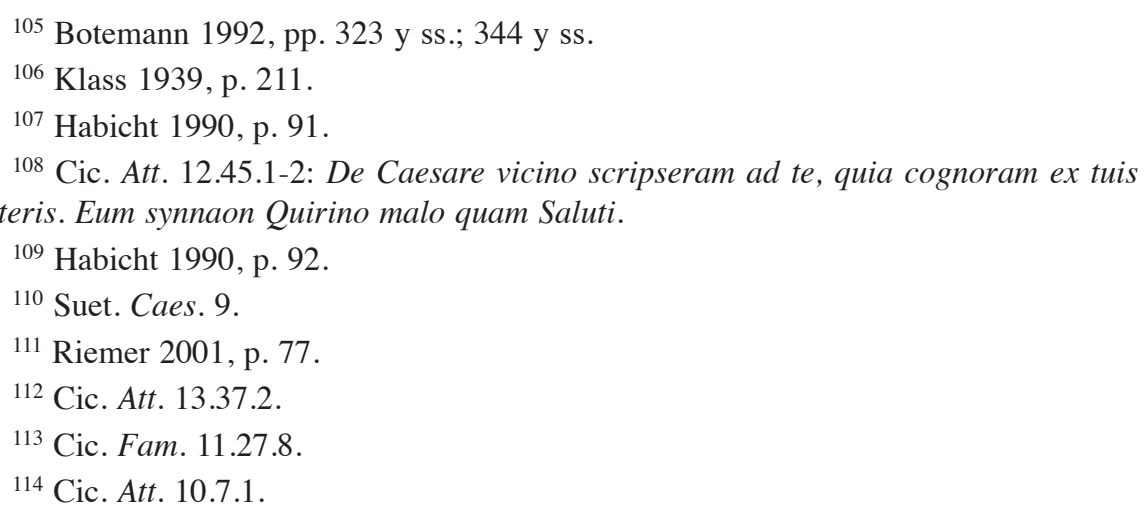


matter, peregrinus rex, among others, in 62 regarding the execution of the plotters - and not in flattery. ${ }^{115}$ Consequently, the concepts of rex and tyrannus belonged to the generally accepted phrases of rhetoric in Roman public affairs in naming men who were striving for autocracy or at least prime power positions, dominatio ${ }^{116}$ In the letter mentioned earlier, written to Atticus on 17 May 45, regarding purchase of property by Caesar, Cicero makes a statement which is open for interpretatio multiplex, that he would like to see Caesar close to Quirinus rather than to Salus. ${ }^{117}$ The background of the text is provided by the fact that the villa purchased by Caesar was located near to the Salus and Quirinus temple, and Cicero wished Caesar the fate of Quirinus rather than salus, that is, welfare and health. ${ }^{118}$ Quirinus as a Roman god was quite often identified with Romulus, who founded Rome but was later assassinated since he ruled as a tyrant - so Cicero wished a similarly bloody end for Caesar too. ${ }^{119}$

The political rhetoric of the period used the name of Romulus as the synonym of tyrant - so, for example, the invective attributed to Sallust called Cicero Romulus Arpinas, ${ }^{120}$ and in 67 Pompey, entrusted to wage war against pirates, wanted to have himself vested with a too wide scope of power by lex Sabina, whereupon C. Calpurnius Piso warned him not to strive for Romulus's laurels if he does not want to come to the same end as Romulus. ${ }^{121}$ Although Cicero did not mention Romulus's name in a negative context - what is more, he comments on the founder of the city in expressly praising context and in acknowledgement, ${ }^{122}$ his positive "Romulus propaganda" did not evoke much response. ${ }^{123}$ Livius discloses two versions on Romulus's death. According to more widely known tradition, Romulus was enveloped by a cloud during a huge storm and ascended to heaven; ${ }^{124}$ according to the legend less kept in evidence,

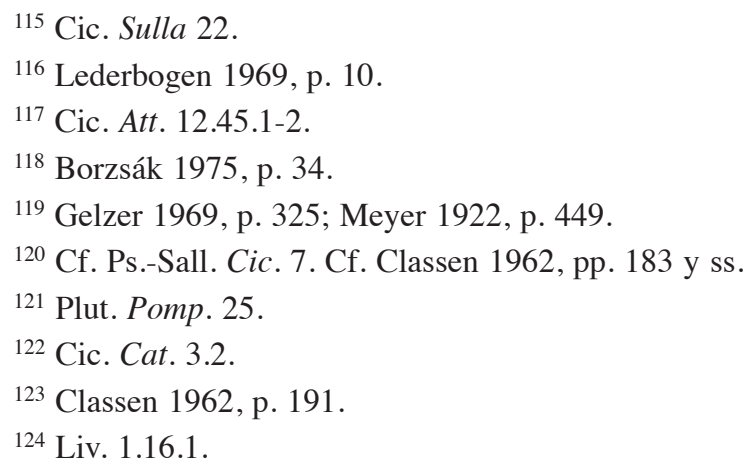


and understandably less popular, in his old age he became a tyrant and was torn to pieces by the senators with their bare hands. ${ }^{125}$ Later on, religious faith identified the last member of the ancient Jupiter - Mars Quirinus triad ${ }^{126}$ with the first King - that is how the legend on the King having become a god, on the one hand, and on the assassinated tyrant, on the other hand, was created. ${ }^{127}$ Caesar took firm steps to introduce the Romulus - Quirinus cult, and in his last years he placed great emphasis on his own legitimisation as "second Romulus". In view of the fact that the apotheosis of statesmen after their death was alien to Roman thinking - the act of deification could take place solely temporarily during the triumph through cultic identification with Iuppiter on the Capitol firmly supported by several preventing rites ${ }^{128}$ - in order to build his own later cult, Caesar resolutely propagated the respect of Romulus Quirinus. ${ }^{129}$ It was not by chance that the senate had a statue erected for him with the inscription "Deo Invicto" in the Quirinus temple - probably upon suggestion from "above", which Caesar did accept. ${ }^{130}$ Cicero mentions the opportunity of this cultic identification a few times, mostly, however, he handles this identification rather cautiously. ${ }^{131}$

At this point it seems to be justified to sum up or repeat what was expounded regarding the motif of killing the tyrant in Pro Milone. Cicero openly calls Caesar tyrannus after his death; ${ }^{132}$ the stoic element of the motif of killing the tyrant can be demonstrated most clearly in the third book of De officiis written in $44 .{ }^{133}$ He declares that the element of killing the tyrant ${ }^{134}$ is in harmony with stoic philosophy to the greatest extent, ${ }^{135}$ which also suits naturalis ratio, ${ }^{136}$ i.e., it is the ulti-

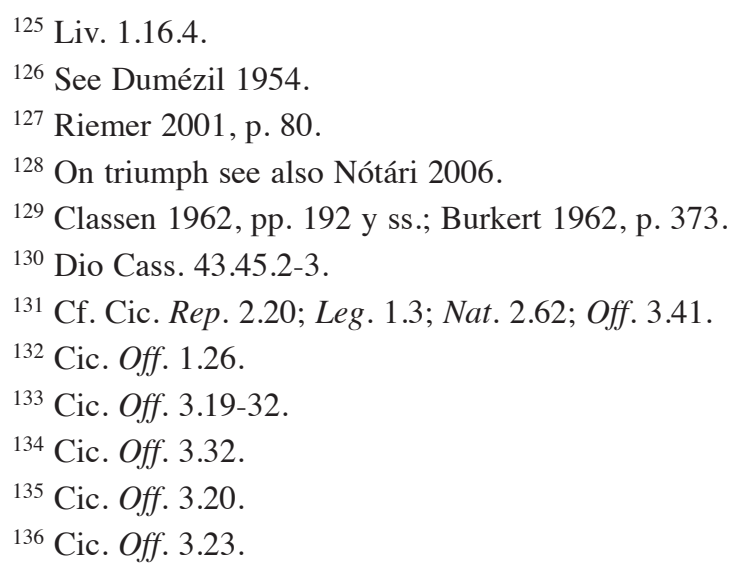


mate conclusion of ethical consideration. ${ }^{137}$ In view of the fact that the tyrant ruins human community and places himself outside the rules of coexistence, ${ }^{138}$ accordingly, these rules are not binding him either. ${ }^{139}$ His reasoning culminates in turning the right of killing the tyrant into the ethical/legal command of killing the tyrant: making common cause with the tyrant is excluded, he must be barred and removed from human community since he is nothing else than a beast having assumed human form. ${ }^{140}$ Phalaris's case is Cicero's most favourite example, and by that he demonstrates that assassination is not only ethically fair but it is definitely a moral obligation (honestum necare), elimination of the tyrant from the community (feritas et immanitas beluae segreganda est). This again is in line with the identification of the tyrannus with belua also present in stoic philosophy, which is clearly formulated in De re publica too ${ }^{141}$ in such form that the tyrannus is the most harmful species of animals, which is the most hateful subhuman being both to gods and humans, that is, it lives merely in figura hominis. ${ }^{142}$ Thus, the key attributes of the tyrant can be described by the following concepts: nulla societas, belua, genus pestiferum, exul, contra leges, contra naturam; i.e., a being close to a subhuman form of existence, whose assassination cannot constitute moral offence just as killing any harmful beast. ${ }^{143}$

In the proceedings against Deiotarus no sentence was passed. After Caesar's death, in De divinatione Cicero puts the statement into Deiotarus's mouth that he did not regret that instead of Caesar, who had deprived him of his kingdom, he sided with Pompey because by doing so he protected the authority of the senate (senatus auctoritatem), the freedom of the people of Rome (populi Romani libertatem) and the dignity of the empire (imperii dignitatem). ${ }^{144}$ This statement (no matter if together with Hermann Strasburger we accept it as authentic ${ }^{145}$ or not)

\footnotetext{
137 Cic. Off. 3.14.19.

138 Cic. Off. 3.21.

${ }^{139}$ Cic. Off. 3.32.

${ }^{140}$ Cic. Off. 3.32.

${ }^{141}$ Cic. Rep. 2.48.

142 Clark-Ruebel 1985, p. 61.

${ }^{143}$ Clark-Ruebel 1985, p. 62.

${ }^{144}$ Cic. Div. 1.27.

${ }^{145}$ Strasburger 1990, p. 50.
} 
from the mouth of a non-Roman as justification of his act sounds insult since he refers to traditional Roman values - just to those by which Caesar, too, legitimised the starting of the civil war. ${ }^{146}$

\section{BIBLIOGRAPHY}

\section{Text and translations}

Cicerón, Tres discursos ante César, México, UnAM, introducción, versión y notas de Juan Antonio Ayala, 1968.

Ciceros Reden. Für M. Marcellus, für Q. Ligarius und für den König Deiotarus, herausgegeben von Fr. Richter und A. Eberhard, Leipzig, Teubner, 1904 ${ }^{4}$

\section{Scholarly studies}

BorzsÁK, S., "Cicero und Caesar. Ihre Beziehungen im Spiegel des RomulusMythos”, in A. Michel-R. Verdière (Hrsg.), Ciceroniana. Festschrift für Kaziemierz Kumaniecki, Leiden, Brill, 1975.

Botermann, H., "Die Generalabrechnung mit dem Tyrannen. Ciceros Rede für den König Deiotarus”, Gymnasium, 99, 1992, pp. 320-344.

Bringmann, K., “Der Diktator Caesar als Richter? Zu Ciceros Reden 'Pro Ligario' und 'Pro rege Deiotaro"', Hermes, 114, 1986, pp. 72-88.

Burkert, W., “Caesar und Romulus Quirinus”, Historia, 11, 1962, pp. 356-376.

Clark, M. E.-Ruebel, J. S., "Philosophy and Rhetoric in Cicero's Pro Milone", Rheinisches Museum, 128, 1985, pp. 57-72.

Classen, J., "Romulus in der römischen Republik", Philologus, 106, 1962, pp. 174-204.

Dahlmann, H., "Clementia Caesaris", in H. Oppermann (Hrsg.), Römertum, Darmstadt, Wissenschaftliche Buchgesellschaft, 1970, pp. 188-202.

DrEXler, H., Die politischen Grundbegriffe der Römer, Darmstadt, Wissenschaftliche Buchgesellschaft, 1988.

DuMÉZIL, G., "Les cultes de la regia, les trois fonctions et la triade Juppiter Mars Quirinus", Latomus, Revue des Études Latines, 13, 1954, pp. 129-139.

Gelzer, M., Cicero. Ein biographischer Versuch, Wiesbaden, F. Steiner, 1969.

НАвіснт, Chr., Cicero, der Politiker, München, Beck, 1990.

Hoben, W., Untersuchungen zur Stellung kleinasiatischer Dynastien in den Machtkämpfen der ausgehenden römischen Republik, Diss. Mainz, 1969.

Hoffmann, Zs., "Divus Iulius", Aetas, 18, 2003/3-4, pp. 12-23.

Klass, J., Cicero und Caesar. Ein Beitrag zur Aufhellung ihrer gegenseitigen Beziehungen, Berlin, E. Ebering, 1939.

${ }^{146}$ Caes. Civ. 1.7.22. Cf. Riemer 2001, p. 35. 
KunKel, W., Die Funktion des Konsiliums in der magistratischen Strafjustiz und im Kaisergericht, I-II, in Kleine Schriften, Weimar, Böhlau, 1974, pp. 151-254.

__, Untersuchungen zur Entwicklung des römischen Kriminalverfahrens in vorsullanischer Zeit, München, Bayerische Akademie der Wissenschaften, 1962.

Meyer, E., Caesars Monarchie und das Prinzipat des Pompeius. Innere Geschichte Roms von 66 bis 44 v. Chr., Stuttgart-Berlin, J. G. Cotta, 1922³.

Mommsen, Th., Römisches Strafrecht, Leipzig, Duncker \& Humblot, 1899.

NIESE, Deiotarus. Nr. 2. In: Paulys Realencyclopädie der classischen Alterthumswissenschaft I-XXIV und I A-X A, Suppl. I-XV. Neue Bearbeitung von G. Wissowa, W. Kroll, K. Mittelhaus und K. Ziegler. Stuttgart-München, J. B. Metzler, 1893-1978. IV. 1901, coll. 2401-2403.

NóTÁRI, T., "From auctoritas to Authority-Remarks on the Roman Concept of Numinousity", Orbis Iuris Romani, 11, 2006, pp. 117-140.

__, "Megjegyzések a modern büntetőeljárási alapelvek római előményeihez" (Remarks on the Roman Precedents of the Basic Principles of Modern Criminal Proceedings), in K. Holé (ed.), A Büntető Törvénykönyv és a Büntető Eljárási Törvény módosításának elméleti és gyakorlati kérdései. (Theoretical and Pracical Questions of the Penal Code and the Act on Criminal Proceedings), Budapest, 2003, pp. 97-103.

Olshausen, E., "Die Zielsetzung der Deiotariana Ciceros", in Lefèvre (Hrsg.), Monumentum Chiloniense. Kieler Festschrift für Erich Burck zum 70. Geburtstag, Amsterdam, Hakkert, 1975, pp. 109-123.

RIEMER, U., Das Caesarbild Ciceros, Hamburg, Dr. Kovač, 2001.

RitTeR, H. “Caesars Verfügung über Kleinarmenien im Jahr 47”, Historia, 19, 1970, pp. 124-128.

Rochlitz, S. Das Bild Caesars in Ciceros 'Orationes Caesarianae'. Untersuchungen zur 'clementia' und 'sapientia Caesaris', Frankfurt am Main-Berlin-BernNew York-Paris-Wien, Lang, 1993 (Studien zur klassischen Philologie, 78).

SCHUMACHER, L., Servus Index. Sklavenverhör und Sklavenanzeige im republikanischen und kaiserzeitlichen Rom, Wiesbaden, Steiner, 1982 (Forschungen zur antiken Sklaverei, 15).

SeEl, O., Cicero. Wort, Staat, Welt, Stuttgart, E. Klett, $1967^{3}$.

Strasburger, H., Ciceros philosophisches Spätwerk als Aufruf gegen die Herrschaft Caesars, Hildesheim, Olms, 1990 (Spudasmata, 45).

Weinstock, S., Divus Iulius, Oxford, Clarendon Press, 1971.

Werner, R., "Caesar und der römische Staat", in Sodalitas. Scritti in onore di Antonio Guarino I, Napoli, Jovene, 1984 (Biblioteca di Labeo, VIII/1), pp. 233-263.

Willrich, H., Cicero und Caesar. Zwischen Senatsherrschaft und Gottkönigtum, Göttingen, Vandenhoeck \& Ruprecht, 1944. 